\title{
NA DÚVIDA: ESCRAVO! DETENÇÃO DE MULHERES E HOMENS LIVRES PELA PRESUNÇÃO DA ESCRAVIDÃO. ANÁLISE DA APLICAÇÃO DA DISPOSIÇÃO DO “ESCRAVO ABANDONADO”, SEGUNDO A LEI DO VENTRE LIVRE
}

\author{
WHEN IN DOUBT, SLAVE! IMPRISONMENT OF FREE MEN AND WOMEN THROUGH \\ PRESUMPTION OF SLAVERY. AN ANALYSIS OF THE APPLIED DISPOSITIVE OF ABANDONED \\ SLAVE ACCORDING TO THE FREE WOMB LAW
}

Paulo Henrique Rodrigues Pereira*

\begin{abstract}
Resumo:
A Escravidão como o tema central do século XIX brasileiro apresentou profundos paradoxos no campo do direito: formalmente enfrentada através da promulgação de normas que poderiam ser lidas como construtoras de um caminho de abolição progressiva, na prática, é possível observar mecanismos e atores institucionais que trabalharam para preservá-la. Tais procedimentos deram-se, muitas vezes, através de um agir jurídico que procurava distorcer, desviar o disposto no campo da legalidade formal. Esse conjunto de práticas atingiu mulheres e homens livres, desestabilizando seus direitos, e precarizando suas expectativas de liberdade.

Nesse balanço entre o direito e o avesso - entre a positivação de uma legalidade formal e a consecução de seu sentido concreto na realidade social -, o presente artigo busca analisar, sob enfoque do direito como prática linguística, parte dessas discrepâncias pela figura do escravo abandonado. Observando as disposições da Lei do Ventre Livre de 1871 sobre tal instituto, essas breves considerações almejam demonstrar a existência de usos e performances formadores de uma espécie de presunção de escravidão, que agia para preservar o escravismo, e que encontrava respaldo na consolidação de uma prática jurídica pela ilegalidade.
\end{abstract}

Palavras-chave: Escravidão. História do Direito. História do Direito Brasileiro. Direito da Escravidão.

\begin{abstract}
:
Slavery as the main topic of the XIX century in Brazil presented profound paradoxes in the field of Law: faced in form through the promulgation of norms that could be read as pavers of a path of progressive abolition, in practice, it is possible to observe institutional mechanisms that worked to preserve it. Such procedures happened most of the times through legal action that sought to distort and deviate what was laid in the field of formal legality. This set of practices hit free women and men, destabilizing their rights and making more and more precarious their expectations of freedom. In this analysis between law and its reverse - between the positivation of a formal legality and the practice of its concrete meaning in social reality, the following article seeks to analyze, through a focus of law as linguistic practice, part of
\end{abstract}

\footnotetext{
* Mestre em Filosofia do Direito, Doutorando, Advogado. Faculdade de Direito do Largo de São FranciscoUSP.
} 
said discrepancies through the example of the abandoned slave. Looking at the dispositives of the Free Womb Law of 1871 on this institute, these brief remarks seek to show the existence of usages and performances that formed what could be known as presumption of slavery in order to preserve it as an institution, and that was aided by the consolidation of a legal practice through illegality.

Keywords: Slavery. History of Law. History of Brazilian Law. Slavery Laws.

No debate de 10 de agosto de 1880, Joaquim Nabuco se utilizava da tribuna para novamente apoiar o que o eufemismo dos parlamentares do século XIX chamava de resolução da questão servil. Com palavras mais claras, que desnaturam menos o objeto, pode-se dizer que Nabuco tratava da tentativa de avançar no sentido da abolição da escravidão no país. O deputado queria incentivar o que chamava de espírito emancipador, propondo que o Império pudesse criar formas de estimular e recompensar aqueles que resolvessem libertar seus escravos.

Assim, registrou-se no Diário de Pernambuco a fala do famoso deputado:

Dizia eu, senhores, que o governo póde fomentar o espirito emancipador, como por exemplo dando titulos de nobreza aos que forravam escravos para a guerra, da mesma forma porque procurou fomentar o espírito patriotico, abrindo as prisões do presidio de Fernando de Noronha ao galé que se quizesse regenerar no serviço da pátria; nós, porém, temos outros meios de honrar esse mesmo espirito, tanto mais digno de louvor quanto mais desinteressado, dando a maior publicidade aos serviços dos benemeritos da emancipação, fazendo que seus nomes corram do norte ao sul, entre os applausos e o reconhecimento do paiz. Para honrar esses serviços estarei sempre pronto a vir á tribuna. (BRASIL, 1880, p. 8).

Dando exemplos dos tais nobres serviços, Nabuco elogiava o então Ministro da Agricultura, Manuel Buarque de Macedo. O ministro, integrante do Gabinete liberal de Saraiva, estaria "incomodado legitimamente com a sorte de tantos escravos ou não escravos, de tantos homens arrastados pela justiça pública e recolhidos à casa de correção para esperar que apareça um dia um senhor imaginário que venha disputar a posse deles". Martim Francisco - também membro do partido liberal -, e então vicepresidente da Câmara, objetou a Nabuco, que aquilo "estava previsto em lei", dizendo que "depois de certo prazo, se os senhores não reclamam, os escravos estão livres".

Nabuco insistiu no tema, dizendo que o Ministro era sensível à questão, e que já havia demandado também do Ministério da Justiça uma solução para o problema. Começou a relatar o caso de um preso chamado Justiniano Terra, que era cidadão oriental, e havia sido recolhido como escravo sem nunca ter havido qualquer dono que o reclamasse. Sob uma suposta dúvida, a Polícia simplesmente o havia posto em prisão aguardando que 
alguém, que ninguém sequer sabia quem poderia ser, se apresentasse como seu legítimo dono.

O deputado foi novamente interrompido, dessa vez por Francisco Sodré. O parlamentar do partido liberal objetara que também esse caso estava já previsto na lei: o escravo abandonado, dizia ele, deveria ser posto em liberdade. Nabuco insistiu que ainda assim ficavam anos e anos na cadeia. Terminou seu discurso dizendo:

Pergunto ao nobre ministro si S. Exc. sabe se a acção da policia é vigilante, constante, todos os dias, sobre esses mercados de carne humana, em que se trafica constantemente nessa cidade... (...) em que se diz que se vende gente livre, em que se passam as maiores miserias e degradações, de que uma sociedade possa infelizmente dar o espetaculo. Pergunto ainda a S. Exc. como funcciona esse serviço por conta do estado, serviço que consiste em inflingir a autoridade pública castigos aos escravos, à vontade dos senhores; pergunto ainda como funcciona esse serviço de açoites para escravos; e se teve alguma execução uma postura, que o passado chefe de de policia, o Sr. Pindahyba de Mattos, fez publicar durante o carnaval, condemnando a cem acoites, o escravo que jogasse o entrudo (...) Pergunto a S. Exc. isio governo tem as vistas sobre estas praças de escravos que são annunciadas pelo Jornal do Commercio, em que foram vendidos, ha pouco, africanos importados depois da lei de 1831. (...) Chamo ainda a attenção do nobre ministro para um processo de que resultou a liberdade de mais de uma centena de homens illegalmente escravisados pela companhia de mineração do Morro Velho, para saber si esta sentença tem tido plena exeção, e que passos tem dado o governo para fazer com que esta companhia ingleza compense o tempo de captiveiro em que reteve aquelles infelizes que eram livres. (BRASIL, 1880, p. 8).

As dinâmicas desempenhadas no diálogo acima revelam muito do estado das coisas no declínio da escravidão brasileira - declínio evidentemente formal. Aos fatos narrados pelo deputado abolicionista, dando conta de homens e mulheres postos em situação de precarização e desaparecimento de sua combalida liberdade, são apresentadas contestações que, em tese, poderiam ser irrefutáveis: tais abusos já haviam sido regulados, solucionados pela lei. A fala de Nabuco é de 1880, e dessa forma é realizada praticamente uma década depois da famosa Lei do Ventre Livre, promulgada em 1871 que, dentre outras coisas, libertava os chamados escravos da nação, os abandonados, os de heranças vagas, além de impor restrições a castigos e punições a escravos. Nessa data, o tráfico negreiro já havia sido proibido quatro vezes - por duas leis e dois tratados internacionais - devendo assim também ser considerado livre o africano trazido ao Brasil ilegalmente nessa condição. 
Ao longo do seu discurso, Nabuco passeia pela demonstração de um alto número de ilegalidades, apresentando casos de negras e negros presos sem nenhum motivo, pela mera suspeita de serem escravos sem sequer dono que os reivindicasse; de indícios de existência de tráfico negreiro; de espaços de comércio, aparentemente conhecido por todos face à naturalidade da sua menção, em que pessoas livres eram vendidas como escravas - conduta, aliás, criminalizada no Império, a partir do Código Criminal de 1830 -; dos serviços de açoites, patrocinados pelo Poder Público; além de mencionar situações notórias de escravização em massa de pessoas livres. Em todos os casos, cobrou providências do Governo. A resposta transcrita nos diálogos foi sempre a mesma: a lei já resolvia aquelas situações.

Essa era a estratégia do escravismo brasileiro: constituindo direitos formais no campo da produção normativa, o Império do Brasil acenava às nações ditas civilizadas que encaminhava providências para se livrar da grande chaga de sua história escravocrata. Evitando que tais direitos se constituíssem na prática, esse mesmo Império abastecia os interesses senhoriais, permitindo a continuidade, relativamente pacificada, do empreendimento servil.

Como linguagem, o Direito é uma prática, depende dos usos e performances desenvolvidas pelos seus atores. ${ }^{1}$ Dessa forma, a contradição existente entre a formalidade dos direitos e a sua realização efetiva dá-se pela percepção de que esses usos e performances por vezes operaram em direção ao seu avesso, para dar um sentido radicalmente diferente do previsto no texto legal, formando um discurso validado do escravismo. ${ }^{2}$ Naturalmente, é possível compreender que tal deslocamento não foi acidental. Havia uma operação destinada a apresentar progressos formais, justamente pela segurança de que tais avanços não seriam postos na prática do direito. Tal tática garantiu a permanência de um sistema de privilégios, atuando em esferas sociais absolutamente diferentes, com vistas à formação de uma legalidade real que, como mencionado acima, não pudesse atacar o sistema escravista.

O presente artigo pretende explorar essa contradição através de um exemplo concreto, analisando o instituto do escravo abandonado. Compreendendo o espaço normativo do previsto acerca do abandono, analisando alguns casos concretos e explorando contextos articuladores dos indícios aqui mencionados, pretende-se apresentar uma breve noção das formas e estratégias de utilização do direito nas tensões que a servidão provocou na vida nacional.

Muitas podem ser as referências teóricas a esse respeito. Pode-se citar Ricoeur (1968d).

Para a importância, conceito e método acerca de uma história dos discursos, Pocock (2013, p. 9). 
1. Um sistema de operação legal de ilegalidades: as situações de precarização de liberdade e direitos

O jornal Opinião Liberal, publicado na capital em 1870, trazia um texto indignado. Dizia o autor que o que se passava neste país de D. Pedro II precisava chegar aos ouvidos do mundo civilizado, à medida que somente em tal lugar fatos tão bárbaros e execrados, como os que ele denunciava, podiam ocorrer. A revolta dava-se por conta de João Fernando Barcellos, negro que seria vendido como escravo abandonado em alguns dias. Sobre João, dizia o autor, que era "natural de Porto Alegre, ex cabo de esquadra do $4^{\circ}$ corpo de caçadores a cavallo de $1^{\circ}$ linha do exercito, tendo feito campanha do Paraguaye tomado parte em diversos combates até o do Estabelecimento". Após passagem corajosa e honrosa pela guerra, fora ferido, e posto em navio que deveria levá-lo novamente ao Brasil.

No transcurso de retorno foi preso como escravo de José Joaquim de Oliveira, e recolhido à prisão com o nome de Antonio. Ocorre que ninguém nunca reclamou a sua propriedade, nem mesmo o tal José de Oliveira. Pareceria, portanto, bastante razoável supor que João era homem livre. A prova não foi suficiente aos olhos do juízo da provedoria, e melhor sorte não ocorreu ao herói da guerra do Paraguai que não o de ser posto à venda como escravo abandonado.

"Será Barcellos realmente escravo? É licito duvidar, desde que, quem se reputa com direito a ele, o abandona sem provar o dominio" inquiriu o indignado subscritor do artigo jornalístico. Prosseguiu dizendo que "E quando escravo fosse; já estará tão desgraçado este paiz, que não possa remir do captiveiro um homem que por elle arriscou sua vida, derramou seu sangue", tendo ainda merecido postos no exército. Ainda que tivesse sido escravo, reflete o autor, o fato de estar abandonado - considerando que o proprietário, existente ou não, nunca buscou retomar sua posse - não deveria ser suficiente para libertá-lo?

Finaliza dizendo:

(...) por mais que os pretos, recolhidos á detenção, por suspeitos de serem escravos, affirmem que são livres, ainda mesmo que ninguem appareça requisitando-os, são sempre vendidos em praça como bens de evento!

Deste modo não é a liberdade que se presume, mas sim o captiveiro.

(...)

Redusam a escravidão os proprios defensores do pavilhão auri-verde; vendam-os, por amor de algumas centenas de mil reis que lhe entram para os cofres; mas tenham ao menos a nobreza de se mostrar taes quais são - barbaros, reprobos da civilisação e da humanidade. 
Não podendo contrabandear na costa d'Africa com medo de inglezes, os estadistas do sr. d. Pedro II escravisam no interior do paiz, á face do sol, contando com a impunidade... (DEFENSOR, 1870, p. 2).

A incivilidade atacada no Opinião Liberal talvez pudesse ter sido, um ano depois, resolvida com a Lei do Ventre Livre que determinou expressamente a liberdade do escravo abandonado. Pelo menos para Calisto, isso não ocorreu. Em 1879, O Paranaense apresentou uma carta sua à imprensa. Nela, reclamava apontando que há tempos havia requerido ao juiz municipal que nomeasse um depositário e um curador para si próprio, na esperança de que a sua condição de escravo abandonado pudesse ser imediatamente reconhecida. Aparentemente, Calisto tinha condições de provar que era escravo abandonado, pois oferecia como testemunhas seis homens livres, e, para o caso de que esses não satisfizessem o juiz, sugeria a oitiva de qualquer um dos moradores de Rio dos Patos. (CALISTO, 1979). Um homem que arrole aleatoriamente qualquer cidadão de um vilarejo para servir-lhe de testemunha parece ter bastante confiança no seu pleito.

Calisto, embora fosse escravo abandonado, conforme as provas que pretendia produzir, também não estava livre, mesmo depois da promulgação da Lei do Ventre Livre.

O problema não era novo, e de certa forma tratava de, pelo menos, duas situações muito claras. A primeira refere-se ao típico caso de abandono, no qual após utilizar o serviço de um escravizado, o senhor, quando este não apresente mais condições de trabalho, prefere abandoná-lo a ter que lhe sustentar com o mínimo substancial. O Bispo de Pernambuco, em documento constante do compilado de consultas do Conselho Ultramarino realizadas entre 1673 e 1792, diz sobre os proprietários de escravos que "quando lhes adoecia algum escravo lançavam-no às matas à disposição da natureza onde se escapão tornão a recebe-los para o seu serviço, e se a doença é grave la morrem sem cura, sem sacramentos como se fossem brutos". (CAMPOS, 1959, p. 161-162).

Com o tempo, a figura do "escravo abandonado" é evocada nos casos concretos em uma situação bastante diferente, quando uma mulher ou homem livres, ou que viviam como tal, são postos arbitrariamente na prisão à espera de um proprietário que não o quer, ou que sequer existe. Nesse caso, como dito, o argumento de escravo abandonado é usado subsidiariamente ao de condição de liberdade, em lógica pela qual o requerente alega que ainda que fosse escravo, seria livre por ser abandonado, na medida em que não houve reivindicação de propriedade. Nesse caso, a argumentação do instituto do abandono serve à liberdade frente uma detenção arbitrária. No Jornal do Commercio de 1879, uma nota dirigida a um juiz tratava justamente dos "infelizes que ahi jazem encarcerados sem delcito ha um, dous e tres annos, abandonados dos seus senhores, só esperâo de V. Ex. o favor que pela lei de 28 de setembro de 1871, foi garantido ao escravo 
abandonado - e porque se tem essa medida feito esperar por tão largo prazo, recorrem esses miseros á imprensa". (NOTA, 1879).

Os temas se encerram na chamada precariedade estrutural da liberdade no Brasil do século XIX. Para o professor Sidney Chalhoub (2010, p. 34) esse mecanismo se apresenta em um conjunto de condições que afetam os negros brasileiros com "restrições constitucionais aos direitos politicos dos libertos, a interdição dos senhores à alfabetização de escravos e o acesso diminuto de libertos e negros livres em geral à instrução primária", além da fragilidade das concessões de liberdade, pela "possibilidade de revogação de alforrias, as práticas de escravização ilegal de pessoas livres de cor, a conduta da polícia nas cidades de prender negros livres sob a alegação de suspeição de que fossem escravos fugidos". A vida em liberdade da negra e do negro brasileiro no último século escravista era marcada pela tensão da fragilidade do seu status de liberdade.

Keila Grinberg na sua pesquisa sobre escravidão nas fronteiras orientais do Brasil apresenta a história de Joana, que bem ilustra a situação do abandonado, e da escravização ilegal. Retirando a narrativa da publicação do Diário de Comércio de 15 de outubro de 1862, a professora cita a seguinte descrição:

No ano de 1852, tornou o senhor Silveira com toda sua família para a estância de Jescas [no Estado Oriental], de onde se retiraram no fim de 3 meses para um lugar denominado Florida, deixando na estância Joana Felícia e seus parceiros, para serem entregues a senhor moço. Os parceiros de Joana, como eram livres foram saindo de casa até que, na manhã de um dia de 1854, desapareceram todos, ficando Joana Felícia abandonada com sua filhinha, de idade de 2 anos, chamada Georgina. Eram 3 horas da tarde, pouco mais ou menos, Joana Felícia, com sua filhinha no regaço, estava sentada a chorar por não saber o fim de seus parceiros e ver-se completamente abandonada, quando chegaram dois homens, aos quais nunca vira nem conhecia e que, atirando sua filha para o lado, apoderaram-se dela, botaram-na na garupa e fugiram caminhando sempre por dentro de matos e por trás de montanhas, deixando assim de procurarem estrada direita e povoada. Julga-se ser combinação o saírem todos de casa a bem de, a salvo, efetuar-se o roubo de Joana Felícia e para ela não ter a quem pedir socorro. (GRINBERG, 2007, p. 90).

Joana, conduzida pelos indivíduos foi "entregue em casa do senhor Joaquim Brás a um senhor chamado Aparício Barbosa. Este trouxe-a para Pelotas e entregou-a ao finado Felicíssimo Manuel Amarante, para este vendê-la para o Rio de Janeiro; mas, como a família gostasse de Joana Felícia". (GRINBERG, 2007, p. 90). Sua filha, depois se soube tornou-se escrava "senhor Amaro da Silveira, em Jaguarão, devendo também ser livre pelas leis do país". (GRINBERG, 2007, p. 90-91). O exemplo 
de Joana é pedagógico: abandonada, deveria ser livre. Os homens que a aprisionaram não possuíam nenhuma informação sobre o seu status de liberdade e a inseriram em um processo de diversas transações comerciais, trocando-a constantemente de proprietários, técnica que visava dar respaldo jurídico-documental para a sua condição de escrava - por meio dos documentos comprobatórios das transações, e dos seus respectivos pagamentos de tributos.

Em suma, a existência de milhares de pessoas colocadas em condição restritiva de liberdade irregularmente é vasta no período, e atenta contra um conjunto de direitos estabelecidos em ampla legislação sobre o tema. Evidente que boa parte desse estabelecimento se deu apenas formalmente: (i) embora em novembro de 1831, a legislação tenha colocado em liberdade todos os africanos traficados a partir de então, os chamados africanos livres, na prática, o tráfico não fora interrompido, o que gerou a colocação de centenas de milhares de pessoas ilegalmente em condição de escravidão; (ii) além disso, são muito numerosos os casos, como já mencionado acima, de pretos e pretas livres que simplesmente eram postos em escravidão, embora isso contrariasse dispositivos constitucionais e penais; e ainda, (iii) quando não apropriados como escravos particulares, era muito comum que esses cidadãos brasileiros fossem esquecidos em prisões, como escravos fugidos, sem que houvesse nenhuma reclamação a seu respeito. Embora desde 1682, por meio do Alvará de 10 de março, estivesse prevista uma prescrição de 5 anos para a reintegração da propriedade senhorial, é comum casos em que pessoas estiveram presas por períodos muito maiores do que esse.

Em suma, a existência de um amplo conjunto legal restritivo da escravidão deveria promover - o que aliás seria óbvio em matéria de faculdades legais - a natural presunção de liberdade para a negra e o negro que, por qualquer motivo, acabam por ter seu caso apreciado pelo sistema legal brasileiro - justiça e administração. Infelizmente, nem sempre foi possível observar essa saída legal.

2. Os escravos abandonados nos processos judiciais: repertório jurídico invocado e casos concretos

A figura do escravo abandonado, prevista já no Direito Romano, começa a ter aparição desde a época colonial, fortalecendo-se a partir do século XIX. ${ }^{3}$ O Ministério da Justiça, em resposta a questionamento do Presidente da Província da Bahia, em decisão de outubro de 1834, recomenda que "que tendo o senhor abandonado os escravos, $e$ tendo-se recusado à obrigação, que tanto lhe incumbia, direito nenhum pode hoje conservar sobre os ditos escravos, antes devem se reputar livres, mandando-lhe $V . m$.

A esse respeito, a afirmação de Leila Algranti (1988, p. 101). 
passar um titulo, que lhe assegure a sua liberdade”. (NASCIMENTO, 2017. p. 3). Em Decreto de 1857 também já havia previsão para declarar abandonado, o escravizado que fosse recolhido à Casa de Detenção por ordem de seu senhor, caso este não o retirasse em tempo adequado. (BRASIL, 1857).

De qualquer forma, em que pese a citação esparsa na legislação e no repertório jurídico geral antes de 1871, foi com a Lei do Ventre Livre que a figura do escravo abandonado fora finalmente regulamentada, em duas previsões distintas. Em primeiro lugar, seu art. $2^{\circ}$, que dizia que "O Governo poderá entregar a associações por elle autorizadas, os filhos das escravas, nascidos desde a data desta lei, que sejam cedidos ou abandonados pelos senhores". Essa primeira disposição, embora fale do abandono, não é exatamente destinada a essa figura legal: relaciona-se com as regras sobre o cidadão nascido de ventre livre. Entretanto, depois a lei é mais taxativa sobre a liberdade das pessoas nessas condições, ao apontar no $\S 4^{\circ}$ do art. $6^{\circ}$ que seriam postos em liberdade, "os escravos abandonados por seus senhores", completando a sentença ao dizer que "se estes os abandonarem por invalidos, serão obrigados a alimental-os, salvo o caso de penuria" (BRASIL, 1871), em operação que deveria ser ajustada pelo juiz de órfãos.

A primeira regra tratava de uma espécie de modelo de transição para o proprietário que não quisesse utilizar-se dos serviços da criança que poderia ser livre ao atingir a idade limite, conforme previsão da lei. Deve-se recordar que ao contrário do que poderia se interpretar a partir do nome da lei, o ventre não era livre: cabia ao senhor escolher utilizar o serviço compulsório daquele que nascia "livre" até os vinte e um anos, quando então a alforria deveria acontecer. A segunda previsão era taxativa e, em tese, ordenava a liberação de qualquer escravo que pudesse ter sido abandonado pelo seu dono, criando, inclusive, obrigação de sustento nos casos de invalidez. Na regulamentação feita pelo Decreto n. 5.135 - art. 76 - (BRASIL, 1872), essa hipótese poderia ser percebida inclusive quando o senhor, ainda que morasse no mesmo lugar que o escravizado, não demonstrasse autoridade, ou ânimo de sujeição sobre ele.

O espírito da lei era discutido na imprensa nacional. O Noticiador de Minas, dois meses antes da promulgação da lei, dizia que "A proposta com muita razão também considera libertos os escravos abandonados por seus senhores, seja qual fôr o motivo, ou que por consentimento expresso delles se estabelecerem como livres", na medida em que nesse caso se supunha que "o senhor demitiu de si o poder, que sobre elles tinha. A lei reconhece aqui sómente o facto, e garante-o". Além da liberdade, a lei estimava uma segurança social ao escravo velho, ou doente: "Ella porém não se limita a proclamar a 
liberdade do escravo abandonado, mas tambem a assegurar-lhe a vida". (ANALYSE, 1871). Naturalmente, também não faltaram críticas ao registro dessa faculdade. ${ }^{4}$

$\mathrm{Na}$ prática, o entendimento das disposições legais foi também discutido. Como de praxe na história das disputas judiciais do escravismo, rígidas operações de deturpação, inversão de ônus de prova, e construção de sentidos concretos da legislação atuavam no momento de concretizar esses direitos supostamente consagrados no campo da legalidade formal. A legalidade real, efetiva na vida dos cidadãos brasileiros, nem sempre seguia o que uma interpretação simples da legislação poderia sugerir.

Para Luíza, por exemplo, a lei não funcionou por bastante tempo. Nesse caso relatado por Flaviane Ribeiro Nascimento, após anos vivendo sozinha, com sustento próprio, sem nenhuma forma de tutela pelo seu senhor, a ex-escravizada teve que apresentar sua demanda ao Tribunal. Seu caso aparentemente era aquele tipicamente previsto no art. 76 do regulamento da lei: vivia sozinha, sobre sí, com seu próprio dinheiro, sem ter nenhuma obrigação com o suposto proprietário, que a havia recebido por herança anos antes.

Para provar sua condição, Luiza apresentou um abaixo-assinado composto pela assinatura de 13 homens livres. Disseram:

Nós abaixo residentes na freguesia de Santa Bárbara declaramos e provamos, se preciso for, que Luíza, do domínio de José Manuel Pinto, morador no Jundiá, desde o ano de 1879 , reside com seus filhos ingênuos, Rita, Felipa, Jerônima, Pedro, Francelina e Aurélio, em casa própria e com economia própria nesta freguesia, completamente isenta do poder dominial e em verdadeiro estado de abandono, sem receber do mesmo Sr. Pinto nenhuma ajuda para sua subsistência, nem socorro algum em suas moléstias, sustentando os referidos seis filhos ingênuos com seu trabalho, sem que o mesmo seu senhor a mantenha em sujeição e mesmo manifeste querer mantê-la sob a sua autoridade. E por verdade e nos despedindo assinamos o presente. Santa Bárbara, 16 de dezembro de 1883. (Grifos no original). (NASCIMENTO, 2017, p. 4).

O juiz entendeu que o abaixo-assinado com mais de uma dezena de testemunhas não era válido. Poderia tê-los chamados à oitiva, mas preferiu imaginar que as testemunhas haviam assinado o documento sem consciência plena do que declaravam. Julgou improcedente a ação de Luiza, que acabou por obter vitória apenas depois, no Superior Tribunal da Relação.

Como exemplo, pode-se citar o intrigante texto de $O$ Cearense de que a lei não era necessária, pois tais direitos já existiam. (ESCRAVIDÃO, 1875). 
Em 1884, a ação de Jorge também foi julgada. Gravemente doente, Jorge vivia sob estado de abandonado, o que podia ser verificado pelas suas péssimas condições de vida e cuidados. Na petição, ele baseia seu pedido em argumentos que são intercalados entre a sua alegação de que o seu senhor havia prometido libertar-lhe e de que estava em estado de abandono. Esse caso é um dos típicos da lei, justamente quando o escravo é largado à própria sorte por não ser mais produtivo.

No Jornal do Aracaju de setembro de 1872, O governo da Província responde ao chefe da polícia dizendo que "o facto de achar-se detido na cadeia desta capital um escravo abandonado pelo senhor, por invalido, e a circumstancia de estar o mesmo necessitando de serio tratamento, por ter a sua saude em grave perigo, declara que faça recolher o dito escravo ao hospital de caridade". O governo resolveu conceder um direito adicional que o senhor não tinha pela letra da lei: caso o senhor não retirasse o escravo em 30 dias, este deveria ser posto em liberdade. (GOVERNO DA PROVINCIA, 1872). Nessa linha, é possível encontrar anúncios destinados a identificar possíveis donos de escravos abandonados, como aquele publicado em setembro de 1874 no $O$ Globo que dizia que "pela secretaria da policia da Côrte, se faz publico para conhecimento de quem convier que foi recolhido ao asylo dos mendigos um preto velho de nome Antonio (...) que declara ser abandonado por sua senhora". (ESCRAVO, 1874).

É interessante perceber como as autoridades policiais promovem atos oficiais, não previstos em lei, que procuram resguardar a situação de escravidão. Seja concedendo prazos inexistentes; seja intimando publicamente pessoas que pudessem desconstituir a posição de um preto, ou preta, que, alegando serem livres, deveriam enfrentar a dúvida de uma inversão de ônus da prova factual. O caso de Jorge, citado acima, foi julgado improcedente, pois entendeu o juiz que Jorge não tinha pecúnio para o depósito de sua alforria, exigência prevista em outra hipótese da lei, quando o escravo pretende fazer a manumissão forçada. (LIMA DA COSTA, 2007, p. 81). Todos eram escravos até que se provasse o contrário.

Talvez estejam nos casos de prisão, as situações nas quais tais operações sejam mais evidentes. São muitas as incidências de aparições de pretas e pretos em cadeias públicas sob suspeita de serem escravos fugidos, não importando absolutamente a sua condição civil. Uma observação breve aos jornais da época pode demonstrar desde notas de falecimentos à intimação de pagamentos aos senhores dos supostos escravos pelas despesas ocorridas nas cadeias públicas: o Diário de Pernambuco de 13 de junho de 1877 dizia que "o cadaver do escravo abandonado por seu senhor, de nome Cyrino, de idade 40 annos, preto, fallecido na casa de detenção, mandado pelo Dr. chefe de policia" (CEMITERIO, 1877); ou no mesmo jornal em julho de 1879, o anúncio da morte de José Rebolo, "escravo, abandonado, preto, Africa, 50 annos, solteira, casa de detenção; anemia". (CEMITERIO, 1879). Ou ainda, no Jornal do Commercio de novembro de 
1881, onde se lia "O sr. desembargador chefe de policia officiou hontem ao Sr. chefe de policia do Rio-Grande do Sul pedindo que mandasse intimar ao dono do preto Justino Terra, afim de pagar, no prazo de trinta dias, as despezas feitas com o mesmo preto, findo o qual será este passado á disposição do juizo da provedoria como escravo abandonado". (EMQUANTO, 1881). Mera coincidência: esse é o caso mencionado por Nabuco no debate reproduzido no começo desse artigo.

Embora faltem mais informações sobre os casos acima, talvez não seja exagerado notar que as autoridades públicas, admitindo a condição de escravos abandonados, não tenham postos tais cidadãos em liberdade. Nos casos de falecimento, é possível se evidenciar que embora houvesse constatação clara da situação do escravizado, suas mortes se deram dentro da detenção. No caso de Justino Terra, a sua liberdade acabara condicionada ao pagamento de despesa da detenção, fato que, em tese, não deveria ser apresentado como condicionante para a sua liberdade. Como mencionado, todos esses casos ocorreram após a lei de 1871.

Naturalmente, as conclusões acima podem ser apressadas. Isso porque as pessoas citadas e chamadas de escravos abandonados poderiam estar na casa de detenção por algum crime, e não por estarem simplesmente andando na rua alegando serem livres. Nos casos mencionados abaixo, entretanto, essa hipótese não é possível. Nesses litígios, ambos patrocinados pelo importante abolicionista Luiz Gama, a dinâmica se revela de forma mais clara através dos pleitos por liberdade a partir da detenção sem crime anotado a não ser o da suspeição de serem escravos de alguém.

No primeiro caso, de 1880, Gama representa em Habeas Corpus o pedido de Ignácia e de outros seis cidadãos. Presos por alegação de que deveriam ser restituídos aos seus senhores, os pacientes aguardavam o aparecimento de um proprietário que nunca viera, ou como eles alegavam, sequer existia. Gama demonstra que nos documentos oficiais da detenção, não há a previsão de nenhum crime ou ocorrência, embora alguns dos seus patrocinados estivessem em custódia há mais de 9 anos. Diversos anúncios haviam sido publicados, e até o momento nem uma única reivindicação de proprietária havia sido registrada. ${ }^{5}$

No outro caso escolhido de Gama, os patrocinados são Leandro e Francisco. No ano de 1881, o advogado representa ambos que estão presos, há mais de dois anos, sem nenhuma acusação formal. Impera sobre eles, novamente, a ideia de que sejam propriedade de alguém, que nunca os reivindicou. Consta do caso, a existência de vários editais procurando por interessados, nenhum deles obtendo qualquer resposta, e por conta

Foram consultados diretamente no Arquivo do Tribunal de Justiça de São Paulo os casos identificados da seguinte forma: Pardo Estevam, Luiza e filhos, José e Felippe, Caetano Preto, Braz e Outros, Luiz, menino, Ex-praça Francisco, Ignácia e outros, Basílio, Apolonia, Roza e Manoel. 
disso, Gama se utiliza da previsão da lei do ventre livre para requerer a liberdade dos seus pacientes. ${ }^{6}$ Novamente, o que vigora é a presunção de escravidão, operando inclusive contra o instituto diretamente estruturado na lei do ventre livre: a do escravo abandonado. Presunção de escravidão empreendida pelo Estado Imperial, através de sua administração de justiça.

Conclusão

A percepção da legalidade efetiva do direito, da lei como se realiza e se apresenta ao mundo, exige uma leitura mais cuidadosa das suas formas, performances e uso nos esforços e avaliações de implementação das normas. Direitos constituídos na lei, e negados na prática, inserem-se em uma ampla categoria de formação de sentidos legais a partir de um bem articulado conjunto de práticas destinadas a defesa de determinados objetivos sociais.

Com o exemplo do escravo abandonado, esse artigo procurou fazer breve incursão nas repercussões da lei do ventre livre, demonstrando as complexidades de implementação do seu programa. $\mathrm{O}$ ataque à sua legalidade, nem sempre se deu de forma direta, como também assim não se fez o discurso de defesa do escravismo nacional. Deformando institutos, invertendo obrigações probatórias, constituindo presunções, os interesses senhoriais puderam, por muitas vezes, negar o direito justamente no estrito cumprimento de suas formas e invocações.

Levadas a sério as disposições legais, seguramente não teria a escravidão chegado tão longe na história nacional. A sua longeva vida institucional contou com consistentes operações que não poderiam ter sido realizadas sem o apoio forte e comprometido de parte da comunidade jurídica nacional. Negando ou aplicando a legalidade, coube ao direito ajudar a formar parte da história social da escravidão.

São Paulo, setembro de 2018.

Arquivo do Tribunal de Justiça de São Paulo, ibidem. 


\section{Referências}

ALGRANTI, Leila Mezan. O feitor ausente: estudos sobre a escravidão urbana no Rio de Janeiro (1808-1822). Petrópolis: Vozes, 1988.

ANALYSE e commentario critico da proposta do governo imperial ás camaras legislativas sobre o elemento servil. Noticiador de Minas, Minas Gerais, 18 jul. 1871. Disponível em: http://memoria. bn.br/docreader/DocReader.aspx?bib=767042\&pagfis=1068\&pesq=escravo $\% 20$ abandonado. Acesso em: 1 nov. 2018.

BRASIL. Camara dos Deputados. Discurso pronunciado na Sessão de 10 de agosto de 1880 (continuação). Diário de Pernambuco, Pernambuco, 27 ago. 1880. Disponível em: http://memoria. bn.br/docreader/DocReader.aspx?bib=029033_06\&PagFis=1578\&Pesq=escravo\%20abandonado. Acesso em: 1 nov. 2018.

BRASIL. Decreto n. 1.896, de 14 de fevereiro de 1857. Dá providencias a respeito dos escravos demorados na Casa de Correcção da Côrte. Portal da Câmara dos Deputados, Brasília, DF, fev. 1857. Disponível em: https://www2.camara.leg.br/legin/fed/decret/1824-1899/decreto-1896-14fevereiro-1857-557885-publicacaooriginal-78627-pe.html.

BRASIL. Decreto n. 5.135, de 13 de novembro de 1872. Approva o regulamento geral para a execução da lei n. 2.040 de 28 de Setembro de 1871. Portal da Câmara dos Deputados, Brasília, DF, nov. 1872. Disponível em: https://www2.camara.leg.br/legin/fed/decret/1824-1899/decreto5135-13-novembro-1872-551577-publicacaooriginal-68112-pe.html.

BRASIL. Lei n. 2.040, de 28 de setembro de 1871. Declara de condição livre os filhos de mulher escrava que nascerem desde a data desta lei, libertos os escravos da Nação e outros, e providencia sobre a criação e tratamento daquelles filhos menores e sobre a libertação annaul de escravos... Portal do Planalto, Brasília, DF, set. 1871. Disponível em: http:/www.planalto.gov.br/ccivil_03/ leis/lim/LIM2040.htm.

CALISTO. Lapa. O Paranaense, Curitiba, 19 out. 1879. Disponível em: http://memoria.bn.br/ docreader/DocReader.aspx ?bib=248261\&pagfis $=342 \&$ pesq $=$ escravo $\% 20$ abandonado. Acesso em: 1 nov. 2018.

CAMPOS, Ernesto de Sousa. Aspectos da assistência médica na época do Brasil-Lusitano e do Brasil-Reino: séculos XVII-XVIII. Revista do Instituto Histórico e Geográfico de São Paulo, São Paulo, v. 55, p. 153-174, 1959. Disponível em: http://ihgsp.org.br/wp-content/uploads/2018/03/Vol55.pdf. Acesso em: 1 nov. 2018.

CEMITERIO publico: obituário do dia 10 de junho de 1877. Diário de Pernambuco, Pernambuco, 13 jun. 1877. Disponível em: http://memoria.bn.br/docreader/DocReader.aspx?bib=029033_05\&pa gfis $=17735 \&$ pesq=escravo\%20abandonado. Acesso em: 1 nov. 2018. 
CEMITERIO publico: obituário doidia 16 do corrente. Diário de Pernambuco, Pernambuco, 19 jul. 1879. Disponível em: http://memoria.bn.br/docreader/DocReader.aspx?bib=029033_05\&pagfis=22 786\&pesq=escravo\%20abandonado. Acesso em: 1 nov. 2018.

CHALHOUB, Sidney. Precariedade estrutural: o problema da liberdade no Brasil escravista (século XIX). Revista História Social, Campinas, n. 19, p. 33-62, segundo semestre de 2010. Disponível em: https://www.ifch.unicamp.br/ojs/index.php/rhs/article/download/315/271. Acesso em: 1 nov. 2018.

DEFENSOR da honra nacional vendido em hasta pública, Um. Opinião Liberal, Rio de Janeiro, 14 fev. 1870. Disponível em: http://memoria.bn.br/docreader/DocReader.aspx?bib=359696\&pagfis=9 61\&pesq=escravo\%20abandonado. Acesso em: 1 nov. 2018.

EMQUANTO espera. Jornal do Commercio, Rio de Janeiro, 28 nov. 1881. Disponível em: http:// memoria.bn.br/docreader/DocReader.aspx bib $=364568 \_07 \&$ pagfis $=4472 \&$ pesq $=$ escravo $\% 20$ abandonado. Acesso em: 1 nov. 2018.

ESCRAVIDÃO e a lei, A. O Cearense, Fortaleza, 11 abr. 1875. Disponível em: http://memoria. bn.br/docreader/DocReader.aspx?bib=709506\&pagfis $=10755 \&$ pesq $=$ escravo $\% 20$ abandonado. Acesso em: 1 nov. 2018.

ESCRAVO abandonado. O Globo, Rio de Janeiro, 2 set. 1874. Disponível em: http://memoria.bn.br/ docreader/DocReader.aspx?bib=369381\&pagfis=108\&pesq=escravo\%20abandonado. Acesso em: 1 nov. 2018.

GOVERNO DA PROVINCIA. Expediente do governo do dia 4 de setembro de 1872. Jornal do Aracaju, Sergipe, 14 set. 1872. Disponível em: http://memoria.bn.br/docreader/DocReader.aspx?bi $\mathrm{b}=218790$ \&pagfis $=269$ \&pesq=escravo\%20abandonado. Acesso em: 1 nov. 2018.

GRINBERG, Keila. Escravidão e liberdade na fronteira entre o Império do Brasil e a República do Uruguai: notas de pesquisa. Cadernos do CHDD, Brasília, DF, ano 6, Número Especial, p. 91-114, 2007.

LAFER, Celso. O moderno e o antigo conceito de liberdade. In: . Ensaios sobre a liberdade. São Paulo: Perspectiva, 1980. p. 11-48.

LIMA DA COSTA, Lenira. A lei do Ventre Livre e os caminhos da liberdade em Pernambuco, 1871-1888. 2007. Dissertação (Mestrado em História) - Centro de Filosofia e Ciências Humanas, Universidade Federal de Pernambuco, Recife, 2007.

NASCIMENTO, Flaviane Ribeiro. Uma história de libertandos e as expectativas de liberdade nas últimas décadas da escravidão (Agreste da Bahia). In: SIMPÓSIO DE HISTÓRIA NACIONAL, 29., 2017, Brasília, DF. Anais... Brasília, DF: UNB, 2017. Disponível em: https://www.snh2017.anpuh. org/resources/anais/54/1502844341_ARQUIVO_UmaHistoriadeLiberdade_FlavianeNascimento_ ANPUH2017.pdf. 
NOTA dirigida a um juiz da provedoria. Jornal do Commercio, Rio de Janeiro, 12 jan. 1879. Disponível em: http://memoria.bn.br/DocReader/364568_06/18929?pesq=escravo\%20 abandonado. Acesso em: 1 nov. 2018.

POCOCK, John Greville Agard. Linguagens do ideário político. Tradução Fábio Fernandez. São Paulo: EDUSP, 2013.

RICOEUR, Paul. A história da filosofia e a unidade do verdadeiro. In: Ricoeur, Paul. História e verdade. Tradução de F. A. Ribeiro. Rio de Janeiro: Forense, 1968a. p. 45-60.

RICOEUR, Paul. História da filosofia e historicidade. In: Ricoeur, Paul. História e verdade. Tradução de F. A. Ribeiro. Rio de Janeiro: Forense, 1968b. p. 66-80.

RICOEUR, Paul. Nota sôbre a história da filosofia e a sociologia do conhecimento. In: Ricoeur, Paul. História e verdade. Tradução de F. A. Ribeiro. Rio de Janeiro: Forense, 1968c. p. 61-65.

RICOEUR, Paul. Objetividade e subjetividade em história. In: Ricoeur, Paul. História e verdade. Tradução de F. A. Ribeiro. Rio de Janeiro: Forense, 1968d. p. 23-44. 